\title{
Centralised or Decentralised Banking Supervision? Evidence from European Banks
}

Avignone, Giuseppe; Altunbas, Yener; Polizzi, Salvatore; Reghezza, Alessio

\section{Journal of International Money and Finance}

DOI:

https://doi.org/10.1016/j.jimonfin.2020.102264

Published: 01/02/2021

Peer reviewed version

Cyswllt i'r cyhoeddiad / Link to publication

Dyfyniad o'r fersiwn a gyhoeddwyd / Citation for published version (APA):

Avignone, G., Altunbas, Y., Polizzi, S., \& Reghezza, A. (2021). Centralised or Decentralised Banking Supervision? Evidence from European Banks . Journal of International Money and Finance, 110, [102264]. https://doi.org/10.1016/j.jimonfin.2020.102264

\footnotetext{
Hawliau Cyffredinol / General rights

Copyright and moral rights for the publications made accessible in the public portal are retained by the authors and/or other copyright owners and it is a condition of accessing publications that users recognise and abide by the legal requirements associated with these rights.

- Users may download and print one copy of any publication from the public portal for the purpose of private study or research.

- You may not further distribute the material or use it for any profit-making activity or commercial gain

- You may freely distribute the URL identifying the publication in the public portal ?
}

Take down policy

If you believe that this document breaches copyright please contact us providing details, and we will remove access to the work immediately and investigate your claim. 


\title{
Centralised or Decentralised Banking Supervision? Evidence from European Banks
}

\begin{abstract}
This paper analyses the impact of the Banking Union on European bank credit risk. Specifically, we investigate the effect that the establishment of the Single Supervisory Mechanism has had on the credit risk of the banks it supervises in comparison to financial institutions that are still supervised by National Supervisory Authorities. We analyse a sample of 746 European banks over the period 2011-2018, by means of a difference-in-differences methodology. We provide empirical evidence that Single Supervisory Mechanism supervised banks reduced credit risk exposure compared to banks supervised by National Supervisory Authorities, suggesting that the Banking Union has successfully reduced the riskiness of the European banking sector. Our results passed a battery of robustness tests that support the reliability of our analysis. Our contribution sheds light on the benefits of centralised versus decentralised supervision, on the effectiveness of the current supervisory system in Europe, and on its impact on European bank risk.
\end{abstract}

Keywords: Banking Union; Bank Credit Risk; Banking Supervision; Regulation; Differencein-Differences

JEL: G20; G21; G28. 


\section{Introduction}

The role of supervisory authorities is crucial for the stability of the banking sector (Barth et al., 2004; Basel Committee on Banking Supervision, 2006). Weaknesses in regulation and supervision are widely considered amongst the main determinants of the global financial crisis (GFC) (Chan-Lau, 2010; Levine, 2010; Merrouche and Neir, 2010; and Barth et al., 2012). Consequently, banking regulation and supervision have been frequently revised over the last years and the Banking Union has been one of the most important institutional response to the crisis in Europe (Carboni et al., 2017).

The Banking Union was officially established in November 2014 and it is organized in two pillars: (i) the Single Resolution Mechanism (SRM) and (ii) the Single Supervisory Mechanism (SSM). The main objective of the SRM is to guarantee the efficient resolution of failing financial institutions with low costs for taxpayers and for the economy as a whole. The other pillar of the Banking Union consists in the establishment of a new supervisory authority, the SSM directly led by the European Central Bank (ECB), whose main responsibility is banking supervision. ${ }^{1}$ However, the SSM is not in charge of supervising all European banks. The Economic and Financial Affairs Council (ECOFIN, 2012) has set the framework and the criteria that the ECB should use to identify systemically important financial institutions (SIFIs) to be supervised by the SSM. The SSM framework regulation identifies four "significance criteria": size, economic importance, cross-border activities, and public financial assistance. To qualify as significant, banks must fulfil at least one of the four criteria, and therefore falling under the direct supervision of the ECB, through the SSM. There are currently 117 banks in 19 countries supervised by the SSM representing 85 percent of total assets of the whole European banking sector (Nouy, 2015). ${ }^{2}$ The SSM directly supervises these banks, whereas national supervisory authorities (NSAs) continue to supervise the remaining part of their national banking system. ${ }^{3}$

There are several reasons why the ECB decided to take charge of the supervision of SIFIs. First, a centralised supervision has been considered an effective way to reduce the excessive credit risk exposure and to tackle the related issue of the outstanding amount of non-performing loans (NPLs) in banks' balance sheet (Enria, 2019). Second, the Banking Union has been a

\footnotetext{
${ }^{1}$ For more information see the Regulation (EU) No 806/2014, available from: https://eur-lex.europa.eu/legal-content/EN/TXT/PDF/?uri=CELEX:32014R0806\&from=EN

${ }^{2}$ For the full list of SSM supervised financial institutions see: https://www.bankingsupervision.europa.eu/ecb/pub/pdf/ssm.listofsupervisedentities201912.en.pdf

${ }^{3}$ A more detailed timetable of the key steps of European Banking Union is provided in Table A1 in the appendix.
} 
way to deal with the problems related to the link between sovereign debt and banking risk (Gerlach et al., 2010; Dermine, 2020). Third, a decentralised supervision may lead to regulatory and supervision arbitrage between credit institutions located in different European member states (so-called regulatory and supervision arbitrage ${ }^{4}$ ) that tend to prefer member states with lax supervision; while a centralised supervision could overcome these issues. Fourth, elevate standards are required not only in financial regulation, but also in banking supervision in order to ensure financial stability. Supervision and regulation complement each other, as without a reliable supervisory framework, financial regulation would be ineffective (De Larosière, 2009).

The literature has proposed two theoretical frameworks to analyse the effectiveness of centralised banking supervision compared to the decentralised model. First, Agarwal et al. (2014) remark the superior effectiveness of a central supervisor model. The authors show that local and supranational supervisors could have different aims, and the former are likely to use their supervisory power in order to protect national banks and to pursue national objectives that might have detrimental effects at systemic wide level. Hence, a supranational supervisor should be better suited to supervise large and systemically important financial institutions, as it is not subjected to this kind of conflict of interest. Second, by analysing the behaviour of a supervisory authorities in the "hub-and-spokes" regime, Carletti et al. (2020) provides another interesting viewpoint. The "hub-and-spokes" regime is a model where a central supervisory authority has juridical power over the decisions concerning banks, and it relies on local supervisors to collect the information necessary to perform its monitoring function. Carletti et al.'s (2020) theoretical model posits that the "hub-and-spokes" regime can succeed in reducing bank risk taking, if local supervisors act according to a centralised mandate.

This paper investigates whether the centralised supervisory framework introduced by the Banking Union via the implementation of the SSM has been effective in reducing credit risk of SSM supervised banks in comparison to those monitored by NSAs. To this aim, we employ a sample of 746 European banks over the period 2011-2018 and a difference-in-differences (DiD) methodology. We focus on credit risk as non-performing loans grew extraordinary following the European sovereign debt crisis ${ }^{5}$. This has pushed policy-makers to prioritise actions to tackle this problem (Enria, 2019) and the new supervisory framework introduced by

\footnotetext{
${ }^{4}$ For more information on the concept of regulatory arbitrage, see Karolyi et al. (2015).

${ }^{5}$ The academic literature has analyzed the influence of banking supervision on credit provisioning. See for instance Fratzscher et al. (2016).
} 
the Banking Union has specifically targeted banks' credit risk exposure (ECB, 2016). To preview our main findings, we provide empirical evidence that the establishment of the SSM has contributed to reduce the credit risk exposure of those financial institutions directly supervised by the SSM. This result supports the idea that the central supervision model is more effective than the decentralised one. Our results stand up well to a battery of robustness checks such as different measures of credit risk and overall risk as well as placebo and sample selection bias tests. These findings suggest that the Banking Union has successfully reduced the riskiness of the European banking sector, and shed light on the effectiveness of the supervisory arrangement in Europe.

This paper contributes to the extant literature in several ways. We contribute to the empirical literature that studies the effectiveness of centralised and decentralised supervisory settings, and to the literature on bank risk, by focusing on the effects of different banking supervision regimes on credit risk. Although other papers have studied different banking supervision settings, the literature that analyses the effects of radical changes in banking supervision by focusing on bank risk is scarce. We also analyse the effects that an under-researched regulatory change (i.e. the Banking Union) has had on bank credit risk.

The paper proceeds as follows. Section 2 reviews the extant literature related to these topics and develops our research hypotheses. Section 3 describes the methodology, variables, and data. Section 4 shows the main results along with several robustness checks. Section 5 concludes.

\section{Literature Review and Hypothesis tests}

\subsection{Literature Review}

The academic debate on the benefits and drawbacks of centralised banking supervision has started well before the GFC and the problems that have induced the European System of Central Banks to establish the SSM. Peek et al. (1999) shed light on an important advantage of the centralised framework, suggesting that it is important to centralise supervisory responsibilities and monetary policy under a single authority, as confidential information on banks help policy makers to predict macroeconomic factors. The debate has focused in particular on whether centralised regulation and supervision lead to higher levels financial stability than a decentralized framework (Laffont and Martimort, 1999; Martimort, 1999; 
Laffont and Pouyet, 2004; among others). Laffont and Pouyet (2004) propose a theoretical analysis to describe the drawbacks of decentralisation in comparison to centralisation. In a decentralised framework, each bank is supervised by a different authority in different countries. This factor generates competition between different cross-border authorities, which leads to an increase in the contractual power of banks, jeopardizing the effectiveness of banking supervision. In this regard, it is worth to mention that a centralized supervision is not optimal for any context. Dell'Ariccia and Marquez (2006a) provide a model that postulates that a centralised supervisory framework is more likely to emerge in countries characterised by a certain degree of homogeneity. Also Barth et al. (2001, 2004, 2008, 2012) cast doubts on the effectiveness of centralised supervision. Through the World Bank's Bank Regulation and Supervision Surveys (BRSSs), these authors study the relationship between specific regulatory and supervisory practices and banking-sector development, efficiency, and fragility. They conclude that, while many countries strengthened capital regulations and official supervisory agencies over time, these reforms are not likely to improve neither bank stability nor efficiency. Hence, there is no significant relation between official supervisory power and bank efficiency. In summary, these economic surveys provide conflicting predictions about the impact of regulatory and supervisory policies on bank performance.

The literature on these topics has gained momentum after the financial crisis. An extensive strand of literature argues that inadequate regulation and poor supervision were amongst the main causes of the GFC (Levine, 2010; Merrouche and Neir, 2010; Barth et al., 2012). This has raised important questions on the effectiveness of the regulatory and supervisory framework. De Larosière (2009) has been among the first to advocate a European centralised system of regulation and supervision. According to his report, weak banking supervision was amongst the main determinants of the GFC. De Larosière (2009) stresses that supervision and regulation are interdependent, because without an adequate supervisory framework the renewed financial regulation would be ineffective. Thus, elevate standards are required in both regulation and supervision in order to ensure financial stability.

Schoenmaker (2011) and Obstfeld (2014) use the financial trilemma to highlight the benefits of a centralized supervision. ${ }^{6}$ The financial trilemma assumes that (1) financial integration, (2) financial stability and (3) national financial policies are incompatible. Only two of the three

\footnotetext{
${ }^{6}$ For more information on the financial trilemma see Rodrik (2000).
} 
objectives can be achieved. The financial trilemma suggests that the delicate role of regulation and supervision of financial institutions should be shifted at the European level (Schoenmaker, 2011). Obstfeld (2014), referring to the euro area, suggests that macro-prudential supervision and Banking Union are the solution to ensure financial stability. It is clear that a supranational central supervisory authority would have been a step ahead towards the solution of the financial trilemma. Aside from the literature that analyses the financial trilemma, other studies have supported the idea of a centralised supervision in Europe. Poghosyan and Cihak (2011) state that an important argument in favour of a more centralised banking regulation and supervision in the EU is related to the fact that European bank risks have become increasingly homogenous. In this context, a supranational supervisor would be in the position to fulfil its role more effectively.

Beck et al. (2013) argue that centralisation is able to offset a wide range of national effects for the sake of systemic wide financial stability. However, they also identify some weaknesses of centralised supervision. The first is related to information asymmetry. National supervisors might have a deeper knowledge of their supervised entities, in comparison to a supranational supervisor. Secondly, in case of intervention in support of troubled banks, a different legal framework can lead the supranational supervisor to a longer and more expensive resolution, in comparison to a national supervisor that may be more supportive with its supervised entities. Hence, a sufficient degree of homogeneity in banking regulation is necessary for a central supervisory arrangement to be fully effective.

The current supervisory architecture in Europe is not the only banking supervision framework that is based on both centralised and decentralised supervision. The peculiarities of the U.S. framework provide useful insights to study the effects of different supervisory settings. These aspects have been analysed by Agarwal et al. (2014), who exploit the exogenously predetermined alternation of state (decentralised) and federal (centralised) supervision in the U.S. to analyse the effects of a dual supervisory mechanism. Their study provides empirical evidence that local banking supervisors are more lenient than federal ones. More specifically, local supervisors may have different objectives than those of the central agency and are in general less inclined to intervene. U.S. banks anticipate the different attitude of federal and national supervisors by modifying their loan quality and leverage ratio figures. Under federal regulators, banks report higher NPLs, higher regulatory capital ratios, and lower ROA. Furthermore, there is a greater frequency of bank failures and bank-related issues in states with 
more lenient supervision relative to the federal benchmark. Hence, the accommodating supervision of decentralised supervisors may have detrimental effects for the whole banking system. Overall, centralisation is likely to raise supervisory standards and deal with the perceived laxness and unwillingness to intervene that led to the recent crisis. In contrast, decentralised supervision and different national jurisdictions may create relative advantages amongst the supervisory and regulatory systems, jeopardizing the systemic-wide financial stability (Scott, 1977).

After the establishment of the banking union, some studies have focused on the analysis of its effects. However, notwithstanding the importance of the topic in question, this strand of literature is not yet well developed. Carboni et al. (2017), analysing daily log-returns over a 252 trading-day of 158 listed European banks, assess the impact that the announcement of the names of the banks that were going to be supervised by the SSM has had on their stock prices. Their contribution provides evidence that investors penalized the banks supervised by the SSM, because of the fear of regulatory inconsistencies. In contrast, Sahin and De Haan (2016) find that European bank stock market prices and credit default swap showed no reaction to the Banking Union. A recent paper written by Sáiz et al. (2019) addresses the question as to whether the Banking Union has influenced the contagion mechanism amongst financial institutions and sovereign risk, which was amongst the main goals of the ECB. These authors do not find robust evidence that the Banking Union decreased the contagion between bank stock returns and sovereign risk. Colliard (2020) focuses on bank regulation within the Banking Union, stating that the supervisory architecture may be an important determinant of the regulatory effectiveness. By analysing the short-term effect of the comprehensive assessment before the SSM launch, Fiordelisi et al. (2017) find that banks reduced their lending activities in order to increase their level of capitalisation. Even though there are other studies that investigate various issues related to the Banking Union (Kudrna, 2016; Hüser et al., 2018), the academic literature on this topic is scant. Thus, this topic requires further investigations, as it is important to understand the various effects that the launch of the SSM and the Banking Union has had on the banking system (Colliard, 2020). Lastly, our study is also motivated by the fact that although, an ample literature analyses the impact of regulation on bank behaviour by focusing on bank risk (Fiordelisi et al., 2011; Harris and Raviv, 2014; among others), only a few papers empirically examine bank reactions to changes in the way they are supervised. 


\subsection{Theoretical Framework}

The current European supervisory system entails a close cooperation between national supervisors and the SSM. Consequently, the theories that study the effectiveness of the monitoring function in a multi-supervisor setting (Agarwal et al., 2014; Carletti et al., 2020), and more generally the studies that analyze the benefits of a more integrated supervisory regime (De Larosière et al., 2009; Schoenmaker, 2011) represent fundamental points of reference for our analysis.

Carletti et al. (2020) propose a theoretical framework that is particularly useful for our research setting. They analyse the behaviour of the supervisory authorities in the "hub-and-spokes" regime. It consists in a model where a central supervisory authority has juridical power over the decisions concerning banks, even though it relies on local supervisors to collect the information necessary to perform its monitoring function. The authors themselves admit that their theoretical analysis is inspired by the European banking supervision structure. This model suggests that if the NSAs (spokes) and the SSM (hub) act jointly with the same goals, the effectiveness of the entire supervisory system would be guaranteed. Carletti et al. (2020, pp. 2) also argue that "internal mechanisms need to be devised to guarantee that the "spokes" act according to the centralized mandate. Various elements of the institutional design in the banking union in Europe [...] go in this direction. For example, in Europe, onsite inspections at the largest banks are conducted by multicountry teams headed by European Central Bank officials in order to facilitate the exchange of information." Hence, according to this theoretical analysis, the SSM central supervision may be more effective than that of NSAs, resulting in lower levels of risk for SSM supervised banks.

Agarwal et al. (2014) study bank supervisors' decisions in the U.S. framework, by exploiting a legally determined rotation policy that assigns federal or state supervisors to the same bank at predetermined time intervals. Their research question is the following: "Does regulatory effectiveness depend only on written rules, or do the institutions that are entrusted with implementing those rules also matter for regulatory outcomes?". Agarwal et. al. (2014) show that different supervisory authorities implement the same rules inconsistently, as they have different objective functions. More specifically, local supervisory authorities tend to carry out a softer monitoring activity during stressed economic periods, because a tough supervision could increase the probability of bank failure. This circumstance could in turn lead to a reduction of the local lending activity and of national banking jobs (local interest hypothesis). 
In contrast, central supervisors are more concerned about the overall systemic stability, rather than about the geographical distribution of bank jobs and lending supply. According to this reasoning, a central supervisor may perform better than local supervisory authorities, as the former does not have any specific interests in favouring the national banking sector. The central supervisor is focused on the stability at systemic wide level, whilst local supervisory authorities have specific interests on their respective geographic areas. Specifically, local supervisors may compete with each other, as they may want to attract financial institutions from close areas. In order to achieve this goal, they perform a softer monitoring function, giving banks the chance to exploit a regulatory arbitrage and undermining the stability of the whole banking system.

The findings of Agarwal et al. (2014) are fundamental to understand the trade-offs of the distribution of supervisory functions and responsibilities across different authorities. Although European local supervisors might have an advantage in terms of information, as they have been the sole supervisors for a long time, their objective functions are important in determining the outcomes of their supervisory function. For example, NSAs may be softer with distressed banks, if they are too big to fail at national level. Furthermore, NSAs may have a close relationship with their national governments. Thus, according to the local interest theory, a central supervisor should perform a more effective monitoring activity than several local supervisors, as they are focused on specific local issues and not interested in the stability of the financial sector at systemic wide level. Specifically, in our research setting, the ECB should be a better supervisor than NSAs, resulting in a more effective monitoring for SSM supervised banks in comparison to nationally supervised financial institutions. This enhanced supervisory framework should significantly impact the risk exposure level of the financial institutions directly supervised by the SSM. We support this argument in light of the vast literature which remarks that the quality of the supervisory function is an important determinant of bank risk (Barth. et al., 2004; Buch and DeLong, 2008; Maddaloni and Peydró 2011; Lee \& Hsieh, 2014; Shehzad and De Haan, 2015, amongst others) and based on the idea that "a supervisor's job is to collect information about banks' portfolios and, upon obtaining it, to intervene if a bank is deemed to be too risky." (Carletti et al., 2020, pp.1). In particular, since credit risk has been considered an ECB supervisory priority since shortly after the establishment of the Banking Union $^{7}$ (ECB, 2016; Enria, 2019), we contend that the SSM has significantly contributed to

\footnotetext{
${ }^{7}$ For further information see: https://www.bankingsupervision.europa.eu/banking/priorities/npl/html/index.en.html
} 
lessen credit risk for SSM supervised banks. For these reasons, we develop our research hypothesis as follows:

H1: The establishment of the SSM has led to a significant reduction of the credit risk exposure level of SSM supervised financial institutions compared to nationally supervised banks.

\section{Methodology \& Data}

\subsection{Methodology}

We employ a DiD approach to study the effect of the Banking Union on bank credit risk. Various banking studies employ this methodology (Morkoetter et al., 2014; Becchetti et al., 2016; Walker \& Wu, 2019), especially when it comes to evaluate the impact of policy changes (Giannetti \& Jentzsch, 2013; Argimón et al. 2017; Fiordelisi et al. 2017). This methodology has the advantage to use a panel data set up to compare a treated group of banks (those affected by the policy change) with a control group (those unaffected by the policy change). Specifically, we compare the effect of the Banking Union on credit risk for our treatment group, with a control group of European banks that are under the supervision of the SSM. The regression model takes the following form

$$
\left.Y_{i, j, t}=\alpha+\beta_{1} \text { Treated }_{i, j} * \text { Post }_{j, t}\right)+\beta^{\prime} K_{i, j}+\gamma_{j}+\varphi_{t}+\varepsilon_{i, j, t}[1]
$$

Where $Y_{i j t}$ represents our measures of credit risk for bank $i$ in country $j$ at time $t$. Specifically, we use loan loss reserves to gross loans (LLR_GL) and loan loss provisions to gross loan (LLP_GL). Treated is a binary variable equal to unity if bank $i$ in country $j$ is under the supervision of the SSM, 0 if it falls under the NSAs supervision. Post is a binary variable equal to unity in the years following the establishment of the SSM, 0 otherwise. $\beta_{1}$ represents the average difference in LLR_GL and LLP_GL between banks that switched to the SSM supervision and banks that did not. $K_{i, j}$ denotes our vector of control variables. Specifically, we include the logarithm of the bank total asset (Size), total customer deposits-to-total assets (Funding Structure), gross loans-to-total assets (Asset Structure), return on assets (Profitability), and equity-to-total assets (Capitalisation). As for the macroeconomic control variables, we include the economic growth (GDP), inflation and gross domestic saving-to-GDP (Saving Propensity). We include country fixed effects $(\gamma)$ to control for unobservable countryspecific characteristics that can affect LLR_GL and LLP_GL. We also control for time-variant 
shocks over the sample period on bank credit risk with year effects $(\varphi)$. All regressions are estimated with bank-level clustering, thus allowing for correlation in the error terms. We use robust standard errors to control for heteroskedasticity and dependence (Bertrand et al., 2004; Donald and Lang, 2007; Petersen, 2009).

The DiD model must satisfy the parallel trend assumption to ensure suitability to analyse the effect of the SSM on bank credit risk (Bertrand et al., 2004; Imbens and Wooldridge, 2009). According to the parallel trend assumption, changes in the dependent variables over time should be exactly the same in both treatment (banks supervised by SSM) and control groups (banks supervised by NSAs) in the absence of the intervention (the introduction of the Banking Union). Figure 1 shows that the main dependent variables in both treated and control groups, have a similar trend from 2011 to 2014 (pre-treatment period). The assumption holds since the trend lines move together before implementation of the Banking Union in 2014. Fig. 1 shows the level of LLR_GL and LLP_GL, from 2011 to 2014 for both Banking Union affected and non-affected banks. As displayed, LLR_GL and LLP_GL move in the same direction in the pre-treatment period (correlation among the treatment and control is 0.86 for LLR_GL and 0.90 for LLP_GL).

[Insert Figure 1 Here]

\subsection{Data}

We construct a dataset from several sources. Bank balance sheet information are collected from Moody's BankFocus (Bureau Van Dijk), whilst macroeconomic variables are retrieved from World Development Indicators (World Bank). The dataset consists of 19 European countries (Austria, Belgium, Cyprus, Estonia, Finland, France, Germany, Greece, Ireland, Italy, Latvia, Lithuania, Luxembourg, Malta, Netherlands, Portugal, Slovakia, Slovenia, and Spain). Similarly to Fiordelisi et al. (2017), we focus only on credit institutions and financial holding companies $(\mathrm{FHCs})^{8}$ following the classification provided by BankFocus. Table 1 (Panel A) shows the sample divided by bank specialisation and country. Given that BankFocus comprises financial statement data that can either be consolidated or unconsolidated, we include in our dataset the data that are either unconsolidated or consolidated but without an unconsolidated

\footnotetext{
${ }^{8}$ Similarly to Fiordelisi et al. (2017), we do not consider cooperative banks, investment banks, private banking, mortgage banks and savings banks because they have different business models.
} 
subsidiary, in order to avoid the inclusion of duplicate observations. The final sample consists of 746 banks in the Euro area; 95 are supervised by the SSM (treatment group) and 651 supervised by NSAs (control group), over the 2011 - 2018 period. Table 1 (Panel B) provides a snapshot of the number of banks divided by supervisor and country. Bank balance sheets are winsorized at the $1 \%$ and $99 \%$ level to mitigate the influence of outliers.

\section{[ Insert Table 1 Here]}

Descriptive statistics for the dependent variables and other balance sheet and macroeconomic variables in the treatment and control groups prior and after the establishment of the SSM are shown in Table 2. We use the ratios of loan loss reserves-to-gross loans (LLR_GL) as a first measure of bank credit risk (Barry et al., 2011). Altunbas et al. (2007) suggest that higher levels of loan loss reserves can be interpreted as greater bank risk. Therefore, we expect - after the introduction of the new supervisory mechanism - to observe a contraction of the reserve for loan losses among SSM supervised banks in comparison to those banks supervised by NSAs. As a second measure of credit risk, we employ the ratio of loan loss provision-to-gross loans (LLP_GL), which is considered an indicator of asset quality (e.g., Williams, 2004). Previous studies have found that banks increase provisions when they expect credit risk to deteriorate (Bikker and Metzemakers, 2005). Since our expectation is to observe a significant reduction of bank credit risk, we expect to observe a reduction of loan loss provisions for those banks supervised by the SSM after its establishment.

As reported in Table 2, the average value of LLR_GL and the LLP_GL before the introduction of the European Banking Union for treatment and control groups is statistically different. Contrarily, after the introduction of the Banking Union the average value of LLR_GL and LLP_GL between the treatment and control group loses its statistical significance. This primary result indicates that the SSM appears to have reduced the difference in credit risk between SSM and NSA banks. Indeed, after the introduction of the centralised supervisory system, the treated banks have experienced a contraction of LLR_GL and LLP_GL from 5\% to $4.6 \%$ and from $1.2 \%$ and $0.6 \%$, respectively. On the contrary, the control group shows that, after 2014, a slight decrease of LLP_GL (from 1\% to $0.7 \%$ ) and an increase in LLR_GL (from $4.4 \%$ to $4.7 \%$ ).

Balance sheet variables. Panels B and E of Table 2 display summary descriptive statistics for bank balance sheet data divided by the treatment and control group. We include total customer 
deposits-to-total assets (Funding Structure) as a measure of bank funding structure. The relationship between bank funding structure and credit risk is ambiguous. On the one hand, retail deposits are considered a more stable source of funds than wholesale funding (Gatev and Strahan, 2006). Laeven et al. (2014) suggest that customer deposits improve bank performance, while wholesale funding is considered to be a major source of vulnerability. Similarly, Demirgüç-Kunt and Huizinga (2010) argue that an extensive use of non-deposit funding is more profitable but, at the same time, riskier. On the other hand, Bologna (2011) indicates that market funding may be relatively cheaper and it allows more flexibility for banks in financing projects.

We employ the ratio of gross loan-to-total assets (Asset Structure) to control for bank asset structure. This variable indicates whether bank business model is based on traditional lending activities. We expect a positive relationship as banks that engage more in lending activity to be more exposed to credit risk (Altunbas et al., 2007). We also control for bank size (Size), computed as the logarithm of bank total assets. The too-big-too-fail hypothesis suggests a positive relationship between bank size and risk (Stern and Feldman, 2004). However, portfolio diversifications, lower funding costs and better managerial skills may lead to an inverse relationship (Bertay et al., 2013).

The regressions also include a measure of profitability (Profitability). On the one hand, less profitable banks face incentives to take risks in an attempt to boost profitability (Mare, 2015; Poghosyan and Čihak, 2011). On the other hand, profitable banks could use their resources to increase risky lending. Hence, the sign of the expected relationship is unknown. Following Gambacorta and Mistrulli (2004), we employ the ratio of equity-to-total assets (Capitalisation) as a measure of bank capitalisation. While highly capitalised banks can increase their risk exposure, binding capital constraints mitigate banking risk for undercapitalised banks (Gambacorta and Shin, 2018; De Nicolò et al., 2010). Hence, we may expect a positive relationship. However, we cannot exclude the possibility that banks might gamble for resurrection, or that weakly capitalised banks assume greater risks to increase earnings, which, if retained, could strengthen bank equity; thereby improving their soundness (Calem and Rob, 1999). If this is the case, a negative relationship is plausible.

Macroeconomic variables. Panels $\mathrm{C}$ and $\mathrm{F}$ of Table 2 show summary descriptive statistics for the macroeconomic variables. Uhde and Heimeshoff (2009) argue that a deterioration in the 
macroeconomic environment is transmitted to banks credit quality, which in turn, can affect loan loss reserves and provisioning (Schinasi, 2005). Hence, it is of great importance to control for the macroeconomic environment when investigating changes in bank credit risk. We include GDP growth (GDP), as it is one of the main macroeconomic factors that affects credit risk (Blaschke and Jones, 2001). However, GDP growth may have opposite effects on credit risk. On the one hand, GDP growth indicates a stable macroeconomic environment, which is related to a lower probability of bank distress, therefore banks may exploit this situation by increasing risk (Marcucci and Quagliariello, 2008; Poghosyan and Cihak, 2011). On the other hand, several studies find that banks behave procyclically, therefore they increase their risk provisions when the economic environment weakens (Arpa et al., 2001; Guidara et al., 2013).

We also include the ratio of domestic savings to GDP (Saving Propensity). Festic et al. (2011) provide evidence of the relationship between savings and bank credit quality. Greater domestic savings increase bank deposits and liquidity. This, in turn, may boost bank lending and consequently loan loss provisions and reserves. Finally, we control for inflation (Inflation). Gerlach et al. (2005) provide evidence of an inverse relationship between credit risk and inflation. Borrowers' ability to fulfil original obligations improves as inflation erodes the real value of debt. Hence, we expect to observe a negative relationship between credit risk and inflation. ${ }^{9}$

[Insert Table 2 Here]

\section{Empirical Results}

\subsection{Baseline Results}

Table 3 shows the results of our empirical analysis from estimating equation [1] and it is organized in 8 columns. Column 1 and 2 include the coefficient of the interaction between the dummy Treated and the dummy Post together with country- and time-fixed effects. In columns 3 and 4, we add the bank-specific variables and keep both country- and time-fixed effects, whilst in columns 5 and 6, we substitute country- and time-fixed effects with country*time fixed effects. In columns 7 and 8, we present results with banks specific variables, macroeconomic variables and country- and time-fixed effects. Our main interest is the

\footnotetext{
${ }^{9} \mathrm{~A}$ more detailed explanation of the variables and expected signs are provided in Table A2 in the appendix.
} 
magnitude, sign and statistical significance of the coefficient of $\beta_{1}$ that represents the average difference in LLR_GL and LLP_GL between banks that switched to the SSM supervision and those that remained under the supervision of NSAs; denoted in the table as Centralised Supervision dummy.

Our results show that the coefficient of Centralised Supervision dummy is negative and statistically significant in each specification, suggesting that SSM supervised banks (SIFIs) reduced their credit risk after the implementation of the Banking Union in comparison to banks supervised by NSAs. Specifically, SSM banks reduced LLR_GL and LLP_GL by 0.94 and 0.51 percentage points, respectively (columns 1 and 2). This result is consistent with our research hypothesis that a centralised supervisory mechanism is more effective than a decentralised one, as it is neutral from national interests aimed at protecting national banking sectors. Furthermore, these results support the idea that the centralised mandate under which the NSAs operate guarantees the effectiveness of SSM supervision and allows the ECB to achieve its policy objectives in terms of reduction in credit risk (ECB, 2016; Enria, 2019).

Our results are robust to different econometric specifications. In columns 3 and 4, we report the results from regressions augmented with bank control variables where we continue to observe a statistically significant effect of the Centralised Supervision dummy. Only few bankspecific variables are statistically significant. Specifically, we find an inverse relationship between size (Size) and bank risk (LLP_GL). This indicates that portfolio diversification and management quality permit larger banks to limit their exposure to credit risks. We also observe a negative relationship between profitability (Profitability) and both measures of bank risk. This result is in line with the idea that less profitable banks invest in risker assets to boost profits. In columns 5 and 6, we tighten our econometric specification replacing year and country fixed effects by including country*time fixed effects to account for time varying country-level unobservable heterogeneity. As displayed, the coefficient Centralised Supervision, although slightly smaller in magnitude, keeps the significance level providing further validity of our estimation. Finally, columns 7 and 8 report the results by including additional country-specific controls. While the coefficient of the interaction dummy maintains the statistical significance level, the coefficient of inflation (Inflation) displays a negative relationship with banking risk. This suggests that very low inflation levels are usually associated to deteriorated macroeconomic condition and/or slow economies and, consequently, 
to higher credit risk. Finally, we find that GDP growth (GDP) is positively related to LLR_GL but negatively to LLP_GL.

[Insert Table 3 Here]

\subsection{Robustness checks}

\subsubsection{Non-Performing Loans and Z-Score}

We test the robustness of our results to a different definition of the dependent variable, by using Non-Performing Loans (NPL Ratio) ratio as an alternative credit risk measure. Several studies have used NPL ratio as proxy for bank credit risk (Berger and De Young, 1997; Williams, 2004, among others). In addition, in order to understand whether the results of our analysis are driven solely by credit risk, we use Z-score as an alternative dependent variable ${ }^{10}$, which represents an overall measure of banking risk (Agoraki et al., 2011; Laeven and Levine, 2009; Beck et al. 2013; Mohsni and Otchere, 2014). The Z-score indicates the number of standard deviations that return on assets have to fall below the average for the bank to become insolvent. A high Z-score suggests a sound bank, which is unlikely to fail (Delis and Staikouras, 2011). Most credit risk proxies are affected by the problem that they assume a backward-looking approach and are procyclical (Laeven and Majnoni, 2003; Bikker and Metzemakers, 2005). In contrast, the Z-score can be interpreted as a forward-looking measure of risk, as the variance at the denominator captures potential changes in bank risk level (Delis and Staikouras, 2011).

We use the logarithmic version of both NPL ratio and Z-Score, to avoid problems owing to the skewness in the distribution (Baselga-Pascual, 2015). The two new regressions (Table 4, panel A) show that the Centralised Supervision dummy is negative and statistically significant, which indicates that the banks supervised by SSM have reduced both credit and overall risk since the introduction of the new supervisory system (columns 1, and 2). The results of this robustness check are consistent with those of our previous specification, confirming the validity of the baseline model. ${ }^{10} Z_{i, t}=\frac{R O A_{i, t}+E A_{i, t}}{\sigma(R O A)_{j, t}}$; where ROA is return on assets for bank $i$ at time $t$, EA is the ratio of equity-to-total assets,
and $\sigma(\mathrm{ROA})$ is the standard deviation of ROA in country $j$ at time $t$. 


\subsubsection{Placebo test}

The results of our DiD estimation might be driven by other events occurred before the sample period we are analyzing. Hence, we investigate whether there have been other factors that have influenced bank credit risk before the establishment of the SSM. To rule out this possibility we create a fictitious post dummy starting in 2012 and study its effect over the 2009-2018 time horizon, extending our sample period of two years. The results reported in Panel B of Table 4 show that the coefficient of the dummy variable is not statistically significant for any of the dependent variables (columns 3 and 4). This finding supports our original hypothesis that the reduction of the risk exposure level of SSM supervised financial institutions is associated to the Banking Union, rather than to other past events. Moreover, since the Banking Union has been announced in 2012, we also exclude the possibility that the results were associated to the announcement of the Banking Union, rather than its actual implementation.

\subsubsection{Removing Germany and France}

We also test whether our results are driven by a sample selection bias. We remove Germany and France from our sample, as they have the largest number of banks in the sample (110 and 115 banks, respectively). Firstly, we remove all German banks from our original sample. Secondly, we proceed removing all banks located in France. Panels C and D of Table 4 show that the results are qualitatively unchanged from our baseline model, confirming that our results are not affected by a sample selection bias.

\section{[Insert Table 4 Here]}

\subsubsection{SSM supervision in non-GIPSI countries}

The results of our analysis might be driven by the sovereign debt crisis shock that hit some European countries during the 2010-2012 period. During the sovereign debt crisis in Europe, the link between sovereign and banking risk increased considerably, and it was marked in weaker countries (De Bruyckere et al., 2013). Shambaugh (2012) uses the acronym GIPSI to represent the five most troubled economies of the Eurozone ${ }^{11}$. Their weakness is due to the fact that access to government bond markets became difficult during the crisis (Popov and Van Horen, 2013). Several banks had an excessively large exposure in domestic bonds, and

\footnotetext{
${ }^{11}$ They are the following: Greece, Italy, Portugal, Spain and Ireland.
} 
therefore the sovereign weaknesses were transmitted to the banking system (Neri, 2013; Acharya et al., 2015; De Marco, 2019). By analysing Italian banking industry, Bofondi et al. (2018) identify a causual link between the sovereign debt crisis and bank credit supply. Specifically, this crisis resulted in a significant reduction in lending, which is in turn associated to lower levels of bank credit risk (Salas and Saurina, 2002; Dell'Ariccia and Marquez, 2006b; Foos et al., 2010).

In order to rule out the hypothesis that our results might be driven by the sovereign debt crisis, we remove the GIPSI countries from our sample, as they were the most affected by this crisis. If our baseline model is robust, we should observe, ceteris paribus, a reduction in banking risk in non-GIPSI countries. In the non-GIPSI subsample (Table 5), the Centralised Supervision dummy is still statistically significant for both dependent variables, suggesting that credit risk exposure of SSM supervised banks located in non-GIPSI countries has reduced in comparison to the financial institutions monitored by NSAs. This result supports the reliability and robustness of our baseline model.

[Insert Table 5 Here]

\section{Conclusion}

The Banking Union has been the most transformative supervisory reform in the European banking system. The ECB, through the SSM, directly supervises 117 banks in 19 countries, whereas the NSAs continue to supervise the remaining part of their respective national banking system. By drawing on the theoretical models that analyse the benefits of centralised supervision over decentralised supervision (Agarwal et al., 2014; Carletti et al., 2020), and on the extensive strand of literature that has shown that the quality of the supervisory function is an important determinant of bank risk (Barth et al. 2004; Buch and DeLong, 2008; Maddaloni and Peydro, 2011; Shehzad and De Haan, 2015) we study the effects of the European Banking Union on bank credit risk. We analyse a sample of 746 European banks over the period 20112018 by means of a DiD methodology to distinguish the banks that are under the SSM central supervision from those that are still supervised by NSAs.

We provide empirical evidence that banks supervised directly by the SSM have reduced their credit risk exposures more than their nationally supervised peers after the establishment of the Banking Union and the introduction of the SSM. This finding is in line with the literature that 
studies the benefits of centralized banking supervision (De Larosière, 2009; Agarwal et al., 2014; Carletti et al., 2020). Our results shed light on the superior effectiveness of centralised supervision compared to a decentralised model in the European context. The alignment of the policy objectives of the supervisory authorities in Europe and the centralised mandate under which the NSAs operate guarantee the effectiveness of SSM supervision and allows the ECB to achieve its policy objectives in terms of reduction in credit risk (ECB, 2016; Enria, 2019).

In light of our findings, we argue that an even more integrated banking supervision might further enhance the stability and the soundness of the European banking system, enabling the banking sector to take advantage of the benefits associated to centralised supervision. 


\section{REFERENCES}

Acharya, V. V., and S. Steffen, (2015). The "greatest" carry trade ever? Understanding eurozone bank risks. Journal of Financial Economics, 115, 215-236. doi: 10.1016/j.jfineco.2014.11.004

Agarwal, S., Lucca, D., Seru, A., \& Trebbi, F. (2014). Inconsistent Regulators: Evidence from Banking. Quarterly Journal of Economics, 129, 889-938. doi: 10.1093/qje/qju003

Agoraki, M.E. K., Delis, M.D., \& Pasiouras, F. (2011). Regulations, competition and bank risktaking in transition countries. Journal of Financial Stability, 7, 38-48. doi: 10.1016/j.jfs.2009.08.002

Altunbas, Y., Carbo, S., Gardener, E.P.M. \& Molyneux, P. (2007). Examining the relationships between capital, risk and efficiency in European banking. European Financial Management, 13, 49-70. doi: 10.1111/j.1468-036X.2006.00285.x

Argimón, I., Dietsch, M., \& Estrada, A. (2016). Prudential filters, portfolio composition at fair value and capital ratios in European banks. Journal of Financial Stability, 39, 187-208. doi: 10.1016/j.jfs.2017.03.004

Arpa, M., Giulini, I., Ittner, A., \& Pauer, F. (2001). The influence of macroeconomic developments on Austrian banks: Implications for banking supervision. BIS Paper, No. 1/2001.

Barry, T. A., Lepetit, L., \& Tarazi, A. (2011). Ownership structure and risk in publicly held and privately owned banks. Journal of Banking and Finance, 35, 1327-1340. doi: 10.1016/j.jbankfin.2010.10.004

Barth, J., Caprio, G., \& Levine, R. (2001). Banking systems around the globe: do regulations and ownership affect performance and stability?. World Bank Policy Research, Working Paper No. 2325.

Barth, J., Caprio, G., \& Levine, R. (2004). Regulation and Supervision: What Works Best? Journal of Financial Intermediation, 13, 205-248.

Barth, J., Caprio, G., \& Levine, R. (2006). Rethinking Bank Supervision and Regulation: Until Angels Govern. Cambridge University Press, Cambridge, UK.

Barth, J., Caprio, G., \& Levine, R. (2008). Bank Regulations are Changing: For Better or Worse? Comparative Economic Studies, 50, 537-563.

Barth, J., Caprio, G., \& Levine, R. (2012). Guardians of Finance: Making Regulators Work for Us. Brookings-Wharton Papers in Financial Services, 183-240.

Barth, J., Lin, C., Ma, Y., Seade, J,, \& Song, F.M. (2013). Do bank regulation, supervision and monitoring enhance or impede bank efficiency?. Journal of Banking and Finance, 37, 28792892. doi: 10.1016/j.jbankfin.2013.04.030 
Basel Committee on Banking Supervision, (2006). International convergence of capital measurement and capital standards. A revised framework. Comprehensive version. Retrieved from: https://www.bis.org/publ/bcbs128.htm

Baselga-Pascual, L., Trujillo-Ponce, A., \& Cardone-Riportella, C. (2015). Factors influencing bank risk in Europe: Evidence from the financial crisis. The North American Journal of Economics and Finance, 34, 138-166. doi: 10.1016/j.najef.2015.08.004

Becchetti, L., Ciciretti, R., \& Paolantonio, A. (2016). The cooperative bank difference before and after the global financial crisis. Journal of International Money and Finance, 69, 224-246. doi: 10.1016/j.jimonfin.2016.06.016

Beck, T., Demirguc-Kunt, A., \& Levine, R. (2006). Bank supervision and corruption in lending. Journal of Monetary Economics, 53, 2131-2163. doi: 10.1016/j.jmoneco.2005.10.014

Beck, T., Todorov, R., \& Wagner, W. (2013). Supervising Cross-border Banks: Theory, Evidence and Policy. Economic Policy, 28, 5-44. doi: 10.1111/1468-0327.12001

Berger, A. N., \& De Young, R. (1997). Problem loans and cost efficiency in commercial banking. Journal of Banking and Finance, 21, 849-870.

Berger, A. N., DeYoung, R., Genay, H., \& Udell, G. F. (2000). Globalization of financial institutions: Evidence from cross-border banking performance. Brookings-Wharton papers on financial services, 1, 23-120.

Bertay, A. C., Demirgüç-Kunt, A., \& Huizinga, H. (2013). Do we need big banks? Evidence on performance, strategy and market discipline. Journal of Financial Intermediation, 22, 532558. doi: 10.1016/j.jfi.2013.02.002

Bertrand, M., Duflo, E., \& Mullainathan, S. (2004). How much should we trust differences-indifferences estimates?. The Quarterly Journal of Economics, 119, 249-275. doi: $10.1162 / 003355304772839588$

Bikker, J. A., \& Metzemakers, P. A. (2005). Bank provisioning behaviour and procyclicality. Journal of International Financial Markets, Institutions and Money, 15, 141-157. doi: 10.1016/j.intfin.2004.03.004

Blaschke, W., Jones, M. (2001). Stress testing of financial systems: An overview of issues, methodologies and FSAP experiences. IMF Working Paper, No. 01/88.

Bofondi, M., Carpinelli, L., \& Sette, E. (2018). Credit supply during a sovereign debt crisis. Journal of the European Economic Association, 16, 696-729. doi: 10.1093/jeea/jvx020

Buch, C. M., \& DeLong, G. (2008). Do weak supervisory systems encourage bank risk-taking?. Journal of Financial Stability, 4, 23-39. doi: 10.1016/j.jfs.2007.12.002

Calem, P., \& Rob, R. (1999). The impact of capital-based regulation on bank risk-taking. Journal of Financial Intermediation, 8, 317-352. doi: 10.1006/jfin.1999.0276 
Calzolari, G., Colliard, J. E., \& Lóránth, G. (2019). Multinational banks and supranational supervision. The Review of Financial Studies, 32, 2997-3035. doi: 10.1093/rfs/hhy116

Carboni, M., Fiordelisi, F., Ricci, O., \& Lopes, F. S. S. (2017). Surprised or not surprised? The investors' reaction to the comprehensive assessment preceding the launch of the banking union. Journal of Banking and Finance, 74, 122-132. doi: 10.1016/j.jbankfin.2016.11.004

Carletti, E., Dell'Ariccia, G., \& Marquez, R. (2020). Supervisory incentives in a Banking Union. Management Science. doi: 10.1287/mnsc.2019.3448

Chan-Lau, J.A. (2010). The global financial crisis and its impact on the Chilean banking system. IMF Working Paper 10/108.

Colliard, J.E. (2020). Optimal supervisory architecture and financial integration in a Banking Union. Review of Finance, 24, 129-161. doi: 10.1093/rof/rfz004

Council Regulation (EU) No 1024/2013 of 15 October 2013. Retrieved from: https://eur-lex.europa.eu/LexUriServ/LexUriServ.do?uri=OJ:L:2013:287:0063:0089:EN:PDF

De Bruyckere, V., Gerhardt, M., Schepens, G., \& Vander Vennet, R. (2013). Bank/sovereign risk spillovers in the European debt crisis. Journal of Banking \& Finance, 37, 4793-4809. doi: 10.1016/j.jbankfin.2013.08.012

De Larosière, J., (2009). Report of the High-Level Group on Financial Supervision in the EU. European Commission, Brussels. Retrieved from:

https://ec.europa.eu/economy_finance/publications/pages/publication14527_en.pdf

De Marco, F. (2019). Bank lending and the European sovereign debt crisis. Journal of Financial and Quantitative Analysis, 54, 155-182. doi: 10.1017/S0022109018000510

De Nicolò, G., Dell'Ariccia, G.D., Laeven, L., \& Valencia, F. (2010). Monetary Policy and Bank Risk Taking. IMF Working Paper, 10/09.

Delis, M. D., \& Kouretas, G. P. (2011). Interest rates and bank risk-taking. Journal of Banking and Finance, 35, 840-855. doi: 10.1016/j.jbankfin.2010.09.032

Delis, M. D., \& Staikouras, P. K. (2011). Supervisory effectiveness and bank risk. Review of Finance, 15, 511-543. doi: 10.1093/rof/rfq035

Dell'Ariccia, G., \& Marquez, R. (2006a). Competition among regulators and credit market integration. Journal of Financial Economics, 79, 401-430. doi: 10.1016/j.jfineco.2005.02.003

Dell'Ariccia, G., \& Marquez, R. (2006b). Lending booms and lending standards. The Journal of Finance, 61, 2511-2546. doi: 10.1111/j.1540-6261.2006.01065.x

Demirgüç-Kunt, A., \& Huizinga, H. (2010). Bank activity and funding strategies: The impact on risk and returns. Journal of Financial economics, 98, 626-650. doi: 10.1016/j.jfineco.2010.06.004 
Dermine, J. (2020). Banks' home bias in government bond holdings: Will banks in low-rated countries invest in European safe bonds (ESBies)?. European Financial Management, forthcoming. doi: 10.1111/eufm.12259

Donald, S. G., \& Lang, K. (2007). Inference with difference-in-differences and other panel data. The Review of Economics and Statistics, 89, 221-233. doi: 10.1162/rest.89.2.221

ECOFIN (2012). Proposal for a Council Regulation Conferring Specific Tasks on the European Central Bank Concerning Policies Relating to the Prudential Supervision of Credit Institutions. Brussels. Retrieved from:

https://eur-lex.europa.eu/legal-content/EN/ALL/?uri=COM:2012:0511:FIN

Enria, A. (2019). Non-performing loans in the euro area - where do we stand? Speech by Andrea Enria, Chair of the Supervisory Board of the ECB, at the Conference "EDIS, NPLs, Sovereign Debt and Safe Assets" organized by the Institute for Law and Finance, Frankfurt, 14 June 2019. Retrieved from:

https://www.bankingsupervision.europa.eu/press/speeches/date/2019/html/ssm.sp190614 bee $\underline{1 \mathrm{~d} 0 \mathrm{f} 29 \mathrm{c} . \mathrm{en} \cdot \mathrm{html}}$

European Central Bank (2016). ECB Banking Supervision: SSM priorities 2016. Retrieved from:

https://www.bankingsupervision.europa.eu/ecb/pub/pdf/publication_supervisory_priorities_2 $\underline{016 . e n . p d f}$

European Central Bank (2019). List of supervised entities. Retrieved from: https://www.bankingsupervision.europa.eu/ecb/pub/pdf/ssm.listofsupervisedentities201912.e $\underline{\text { n.pdf }}$

Festić, M., Kavkler, A., \& Repina, S. (2011). The macroeconomic sources of systemic risk in the banking sectors of five new EU member states. Journal of Banking and Finance, 35, 310 322. doi: 10.1016/j.jbankfin.2010.08.007

Fiordelisi, F., Marques-Ibanez, D., \& Molyneux, P. (2011). Efficiency and risk in European banking. Journal of Banking and Finance, 35, 1315-1326. doi: 10.1016/j.jbankfin.2010.10.005

Fiordelisi, F., Ricci, O., \& Lopes, F. S. S. (2017). The unintended consequences of the SingleSupervisory Mechanism launch in Europe. Journal of Financial and Quantitative Analysis, 52, 2809-2836. doi: 10.1017/S0022109017000886

Foos, D., Norden, L., \& Weber, M. (2010). Loan growth and riskiness of banks. Journal of Banking and Finance, 34, 2929-2940. doi: 10.1016/j.jbankfin.2010.06.007

Fratzscher, M., König, P. J., \& Lambert, C. (2016). Credit provision and banking stability after the Great Financial Crisis: The role of bank regulation and the quality of governance. Journal of International Money and Finance, 66, 113-135. doi: 10.1016/j.jimonfin.2016.02.015

Gambacorta, L., \& Mistrulli, P. E. (2004). Does bank capital affect lending behavior?. Journal of Financial intermediation, 13, 436-457. doi: 10.1016/j.jfi.2004.06.001 
Gambacorta, L.; and H.S. Shin, (2018). Why bank capital matters for monetary policy. Journal of Financial Intermediation, 35, 17-29. doi: 10.1016/j.jfi.2016.09.005

Gatev, E., \& Strahan, P. E. (2006). Banks' advantage in hedging liquidity risk: Theory and evidence from the commercial paper market. The Journal of Finance, 61, 867-892. doi: 10.1111/j.1540-6261.2006.00857.x

Giannetti, C., \& Jentzsch, N. (2013). Credit reporting, financial intermediation and identification systems: International evidence. Journal of International Money and Finance, 33, 60-80. doi: 10.1016/j.jimonfin.2012.10.005

Gerlach, S., Peng, W., \& Shu, C. (2005). Macroeconomic conditions and banking performance in Hong Kong SAR: a panel data study. BIS Papers, 22, 481-497.

Gerlach, S., Schulz, A., \& Wolff, G. B. (2010). Banking and Sovereign risk in the Euro Area. CEPR Discussion Paper, No. DP7833.

Guidara, A., Soumaré, I., \& Tchana, F. T. (2013). Banks' capital buffer, risk and performance in the Canadian banking system: Impact of business cycles and regulatory changes. Journal of Banking and Finance, 37, 3373-3387. doi: 10.1016/j.jbankfin.2013.05.012

Harris, M., \& Raviv, A. (2014). How to get banks to take less risk and disclose bad news. Journal of Financial Intermediation, 23, 437-470. doi: 10.1016/j.jfi.2014.06.001

Hüser, A. C., Hałaj, G., Kok, C., Perales, C., \& van der Kraaij, A. (2018). The systemic implications of bail-in: a multi-layered network approach. Journal of Financial Stability, 38, 81-97. doi: 10.1016/j.jfs.2017.12.001

Imbens, G. W., \& Wooldridge, J. M. (2009). Recent developments in the econometrics of program evaluation. Journal of Economic Literature, 47, 5-86. doi: 10.1257/jel.47.1.5

Karolyi, G. A., \& Taboada, A. G. (2015). Regulatory arbitrage and cross-border bank acquisitions. The Journal of Finance, 70, 2395-2450. doi: 10.1111/jofi.12262

Kudrna, Z. (2016). Governing the ins and outs of the EU's banking union. Journal of Banking Regulation, 17, 119-132. doi: 10.1057/jbr.2015.15

Laeven, L., \& Levine, R. (2009). Bank governance, regulation and risk taking. Journal of Financial Economics, 93, 259-275. doi: 10.1016/j.jfineco.2008.09.003

Laeven, L., \& Majnoni, G. (2003). Loan loss provisioning and economic slowdowns: too much, too late?. Journal of Financial Intermediation, 12, 178-197. doi: 10.1016/S10429573(03)00016-0

Laeven, L., Ratnovski, L., \& Tong, H. (2016). Bank size, capital, and systemic risk: Some international evidence. Journal of Banking and Finance, 69, 25-34. doi: 10.1016/j.jbankfin.2015.06.022

Laffont, J. J., \& Martimort, D. (1999). Separation of regulators against collusive behavior. The Rand Journal of Economics, 30, 232-262. doi: 10.2307/2556079 
Laffont, J. J., \& Pouyet, J. (2004). The subsidiarity bias in regulation. Journal of Public Economics, 88, 255-283. doi: 10.1016/S0047-2727(02)00139-1

Lee, C. C., \& Hsieh, M. F. (2014). Bank reforms, foreign ownership, and financial stability. Journal of International Money and Finance, 40, 204-224. doi: 10.1016/j.jimonfin.2012.04.013

Levine, R. (2010). An autopsy of the US financial system: accident, suicide, or negligent homicide. Journal of Financial Economic Policy, 2, 196-213. doi: $10.1108 / 17576381011085421$

Maddaloni, A., \& Peydró, J. L. (2011). Bank risk-taking, securitization, supervision, and low interest rates: Evidence from the Euro-area and the US lending standards. Review of Financial Studies, 24, 2121-2165. doi: 10.1093/rfs/hhr015

Marcucci, J., \& Quagliariello, M. (2008). Is bank portfolio riskiness procyclical?: Evidence from Italy using a vector autoregression. Journal of International Financial Markets, Institutions and Money, 18, 46-63. doi: 10.1016/j.intfin.2006.05.002

Mare, D. S. (2015). Contribution of macroeconomic factors to the prediction of small bank failures. Journal of International Financial Markets, Institutions and Money, 39, 25-39. doi: 10.1016/j.intfin.2015.05.005

Martimort, D. (1999). Renegotiation design with multiple regulators. Journal of Economic Theory, 88, 261-293.

Mohsni, S., \& Otchere, I. (2014). Risk taking behavior of privatized banks. Journal of Corporate Finance, 29, 122-142. doi: 10.1016/j.jcorpfin.2014.07.007

Morkoetter, S., Schaller, M., \& Westerfeld, S. (2014). The liquidity dynamics of bank defaults. European Financial Management, 20, 291-320.

Neri, S. (2013). The impact of the sovereign debt crisis on bank lending rates in the euro area. Bank of Italy Occasional Paper, No. 170.

Nier, E. W., \& Merrouche, O. (2010). What Caused the Global Financial Crisis? Evidence on the Drivers of Financial Imbalances 1999-2007. IMF Working Paper, 10/265.

Nouy, D., (2015). The European banking landscape - initial conclusions after four months of joint banking supervision and the main challenges ahead. Speech at the SZ Finance Day in Frankfurt, 17 March. Retrieved from:

https://www.bankingsupervision.europa.eu/press/speeches/date/2015/html/se150317.en.html

Obstfeld, M., (2014). Trilemmas and Tradeoffs: Living with Financial Globalization. Mimeo $U C$ Berkeley.

Peek, J., Rosengren, E. S., \& Tootell, G. M. (1999). Is bank supervision central to central banking?. The Quarterly Journal of Economics, 114, 629-653. doi: 10.1162/003355399556098 
Petersen, M. A. (2009). Estimating standard errors in finance panel data sets: Comparing approaches. The Review of Financial Studies, 22, 435-480. doi: 10.1093/rfs/hhn053

Poghosyan, T., \& Čihak, M. (2011). Determinants of bank distress in Europe: Evidence from a new data set. Journal of Financial Services Research, 40, 163-184. doi: 10.1007/s10693011-0103-1

Popov, A. A., \& and van Horen, N. (2013). The Impact of Sovereign Debt Exposure on Bank Lending: Evidence from the European Debt Crisis. De Nederlandsche Bank Working Paper No. 382. doi: 10.2139/ssrn.2289290

Regulation (EU) No 1022/2013 of the European Parliament. Retrieved from: https://eur-lex.europa.eu/legal-content/EN/TXT/PDF/?uri=CELEX:32013R1022\&from=EN

Rodrik, D., (2000). How Far Will International Economic Integration Go? Journal of Economic Perspectives, 14, 177-186. doi: 10.1257/jep.14.1.177

Sahin, C., \& De Haan, J. (2016). Market reactions to the ECB's Comprehensive Assessment. Economics Letters, 140, 1-5. doi: 10.1016/j.econlet.2015.12.011

Sáiz, M. C., Azofra, S. S., \& Olmo, B. T. (2019). The single supervision mechanism and contagion between bank and sovereign risk. Journal of Regulatory Economics, 55, 67-106. doi: 10.1007/s11149-018-09373-6

Salas, V., \& Saurina, J. (2002). Credit risk in two institutional regimes: Spanish commercial and savings banks. Journal of Financial Services Research, 22, 203-224. doi: 10.1023/A:1019781109676

Schinasi, J.G., (2005). Preserving financial stability. IMF Economic Issues, No. 36/2005.

Schoenmaker, D., (2011). The Financial Trilemma. Economic Letters, 111, 57-59. doi: 10.1016/j.econlet.2011.01.010

Scott, K. E., (1977). The Dual Banking System: A Model of Competition in Regulation. Stanford Law Review, 1, 1-50.

Shambaugh, C.J., (2012). The Euro's three crises. Brookings Papers on Economic Activity, 03/2012. 1-54.

Shehzad, C. T., \& De Haan, J. (2015). Supervisory powers and bank risk taking. Journal of International Financial Markets, Institutions and Money, 39, 15-24. doi: 10.1016/j.intfin.2015.05.004

Stern, G. H., \& Feldman, R. J. (2004). Too Big to Fail: The Hazards of Bank Bailouts. Brookings Institution Press, Washington, D.C.

Uhde, A., \& Heimeshoff, U. (2009). Consolidation in banking and financial stability in Europe: Empirical evidence. Journal of Banking and Finance, 33, 1299-1311. doi: 10.1016/j.jbankfin.2009.01.006 
Walker, M. D., \& Wu, Q. (2019). Equity issues when in distress. European Financial Management, 25, 489-519. doi: 10.1111/eufm.12220

Williams, J. (2004). Determining management behaviour in European banking. Journal of Banking and Finance, 28, 2427-2460. doi: 10.1016/j.jbankfin.2003.09.010 

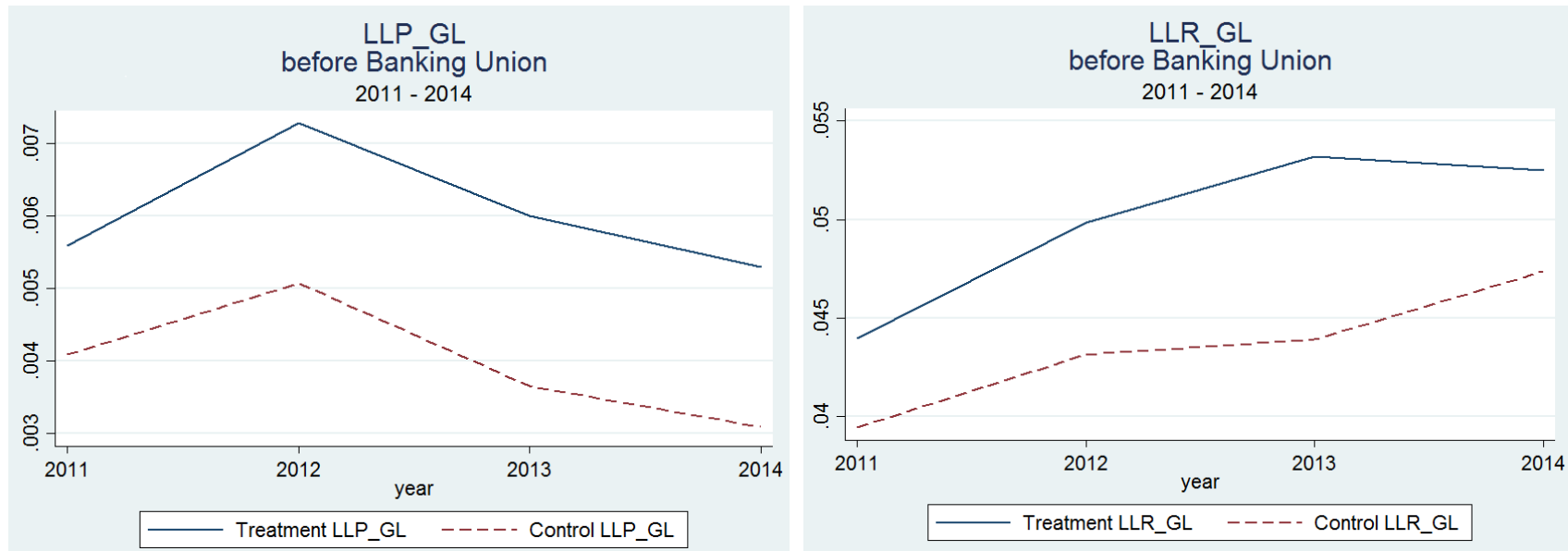

Figure 1. Figure 1 shows the average growth of Loan Loss Provisions / Gross Loans (LLP_GL) and Loan Loss Reserves / Gross Loans (LLR_GL) among treated banks (blue line) and non-treated banks (red dashed line) from 2011-14. In the pre-treatment period, correlation among the treatment and control group is: 0.9021 for LLP_GL and 0.8657 for LLR_GL, indicating that the parallel trend assumption holds.

Notes: LLP_GL is the ratio of loan loss provision-to-gross loans. LLR_GL is the ratio of loan loss reserves-togross loans. 
Table 1

Number of banks by bank specialisation and supervisor.

Panel A

Descriptive statistics divided by specialisation and country

\begin{tabular}{lccc}
\hline & \multicolumn{2}{l}{ Specialisation } & \\
\cline { 2 - 3 } Country & FHC & $\begin{array}{c}\text { Credit } \\
\text { Institutions }\end{array}$ & Total \\
\cline { 1 - 2 } Austria & 3 & 95 & 98 \\
Belgium & 4 & 32 & 36 \\
Cyprus & 1 & 25 & 26 \\
Estonia & 1 & 6 & 7 \\
Finland & 1 & 17 & 18 \\
France & 6 & 109 & 115 \\
Germany & 11 & 99 & 110 \\
Greece & 1 & 6 & 7 \\
Ireland & 1 & 9 & 10 \\
Italy & 3 & 96 & 99 \\
Latvia & 0 & 14 & 14 \\
Lithuania & 0 & 5 & 5 \\
Luxembourg & 3 & 60 & 63 \\
Malta & 1 & 7 & 8 \\
Netherlands & 9 & 28 & 37 \\
Portugal & 4 & 21 & 25 \\
Slovakia & 1 & 9 & 10 \\
Slovenia & 0 & 8 & 8 \\
Spain & 3 & 47 & 50 \\
Overall & 53 & 693 & 746 \\
\hline & & & \\
\hline
\end{tabular}

\section{Panel B}

Descriptive statistics divided by supervisor and country

\begin{tabular}{lccc}
\hline & Supervisor & & \\
\cline { 2 - 3 } Country & & & \\
\cline { 1 - 2 } Austria & NSA & SSM & Total \\
Belgium & 93 & 5 & 98 \\
Cyprus & 29 & 7 & 36 \\
Estonia & 24 & 2 & 26 \\
Finland & 4 & 3 & 7 \\
France & 17 & 1 & 18 \\
Germany & 107 & 8 & 115 \\
Greece & 98 & 12 & 110 \\
Ireland & 3 & 4 & 7 \\
Italy & 7 & 3 & 10 \\
Latvia & 89 & 10 & 99 \\
Lithuania & 11 & 3 & 14 \\
Luxembourg & 3 & 2 & 5 \\
Malta & 56 & 7 & 63 \\
Netherlands & 5 & 3 & 8 \\
Portugal & 33 & 4 & 37 \\
Slovakia & 22 & 3 & 25 \\
Slovenia & 7 & 3 & 10 \\
Spain & 5 & 3 & 8 \\
& 38 & 12 & 50 \\
& 651 & 95 & 746
\end{tabular}

Note: FHC means Financial Holding Companies. NSA indicates National Supervisory Authorities. SSM is the Single Supervisory Mechanism. 
Table 2

Descriptive statistics of control and treatment group prior to and after the introduction of the Banking Union.

\begin{tabular}{|c|c|c|c|c|c|c|c|c|c|c|}
\hline \multirow{3}{*}{ Variables } & \multicolumn{10}{|c|}{ Treatment (SSM) } \\
\hline & \multicolumn{5}{|c|}{ Pre-Banking Union } & \multicolumn{5}{|c|}{ Banking Union Period } \\
\hline & Obs & Mean & St.Dev & $\min$ & $\max$ & Obs & Mean & St.Dev & $\min$ & $\max$ \\
\hline \multicolumn{11}{|c|}{ Panel A: Bank Credit Risk and Overall Risk } \\
\hline LLR_GL & 323 & $5,00 \% * * *$ & $4,60 \%$ & $0,00 \%$ & $24,72 \%$ & 337 & $4,60 \%$ & $4,90 \%$ & $0,00 \%$ & $24,50 \%$ \\
\hline LLP_GL & 345 & $1,20 \% * * *$ & $2,10 \%$ & $-3,20 \%$ & $9,75 \%$ & 356 & $0,60 \%$ & $1,30 \%$ & $-3,30 \%$ & $9,80 \%$ \\
\hline Z-Score & 352 & $2,75^{* * *}$ & 1,42 & $-4,21$ & 5,82 & 369 & $2,99 * * *$ & 1,13 & 0,11 & 6,00 \\
\hline NPL Ratio & 74 & $-2,73 \%$ & $0,97 \%$ & $-4,88 \%$ & $-0,43 \%$ & 146 & $-3,20 \%$ & $0,98 \%$ & $-6,12 \%$ & $-0,54 \%$ \\
\hline \multicolumn{11}{|c|}{ Panel B: Bank Balance Sheet } \\
\hline Funding Structure & 349 & $50,40 \% * * *$ & $21,10 \%$ & $0,37 \%$ & $91,90 \%$ & 368 & $56,40 \% * *$ & $20,20 \%$ & $0,40 \%$ & $90,10 \%$ \\
\hline Asset Structure & 352 & $56,10 \% * * *$ & $22,60 \%$ & $0,41 \%$ & $98,00 \%$ & 369 & $54,97 \% *$ & $21,10 \%$ & $0,40 \%$ & $93,10 \%$ \\
\hline Size & 352 & $17,48 * * *$ & 1,74 & 11,30 & 19,62 & 372 & $17,44 * * *$ & 1,68 & 11,31 & 19,59 \\
\hline Profitability & 352 & $0,19 \% * * *$ & $1,72 \%$ & $-3,92 \%$ & $14,80 \%$ & 369 & $0,54 \% *$ & $1,36 \%$ & $-3,89 \%$ & $14,55 \%$ \\
\hline Capitalization & 352 & $7,46 \% * * *$ & $7,13 \%$ & $1,59 \%$ & $88,02 \%$ & 369 & $8,89 \%$ *** & $7,92 \%$ & $1,98 \%$ & $87,62 \%$ \\
\hline \multicolumn{11}{|c|}{ Panel C: Macroeconomic Variables } \\
\hline GDP & 380 & $0,72 \%$ & $2,70 \%$ & $-9,13 \%$ & $8,56 \%$ & 380 & $2,71 \% * * *$ & $2,56 \%$ & $-0,44 \%$ & $25,16 \%$ \\
\hline Saving Propensity & 380 & $24,97 \%$ & $9,10 \%$ & $8,33 \%$ & $52,35 \%$ & 380 & $27,38 \%$ & $10,23 \%$ & $10,27 \%$ & $57,08 \%$ \\
\hline Inflation & 372 & $1,78 \%$ & $1,23 \%$ & $-1,31 \%$ & $4,98 \%$ & 372 & $0,93 \%$ & $0,97 \%$ & $-1,74 \%$ & $3,72 \%$ \\
\hline \multirow{3}{*}{ Variables } & \multicolumn{10}{|c|}{ Control (NSAs) } \\
\hline & \multicolumn{5}{|c|}{ Pre-Banking Union } & \multicolumn{5}{|c|}{ Banking Union Period } \\
\hline & Obs & Mean & St.Dev & $\min$ & $\max$ & Obs & Mean & St.Dev & $\min$ & $\max$ \\
\hline \multicolumn{11}{|c|}{ Panel A: Bank Credit risk and Overall Risk } \\
\hline LLR_GL & 1397 & $4,40 \% * * *$ & $4,70 \%$ & $0,00 \%$ & $23,70 \%$ & 1538 & $4,70 \%$ & $5,50 \%$ & $0,00 \%$ & $24,50 \%$ \\
\hline LLP_GL & 1866 & $0,96 \% * * *$ & $2,00 \%$ & $-3,30 \%$ & $9,86 \%$ & 1972 & $0,70 \%$ & $1,80 \%$ & $-3,30 \%$ & $9,80 \%$ \\
\hline Z-Score & 2121 & $3,13 * * *$ & 1,29 & $-2,72$ & 6,21 & 2211 & $3,27 * * *$ & 1,23 & $-2,03$ & 6,00 \\
\hline NPL Ratio & 86 & $-2,80 \%$ & $0,92 \%$ & $-4,79 \%$ & $-1,05 \%$ & 182 & $-3,29 \%$ & $1,05 \%$ & $-6,22 \%$ & $-1,07 \%$ \\
\hline \multicolumn{11}{|c|}{ Panel E: Bank Balance Sheet } \\
\hline Funding Structure & 1998 & $56,04 \% * * *$ & $27,00 \%$ & $0,90 \%$ & $92,70 \%$ & 2082 & $59,01 \%$ ** & $26,30 \%$ & $0,40 \%$ & $91,60 \%$ \\
\hline Asset Structure & 2062 & $53,20 \% * * *$ & $27,50 \%$ & $0,40 \%$ & $98,00 \%$ & 2165 & $53,16 \% *$ & $26,70 \%$ & $0,75 \%$ & $96,00 \%$ \\
\hline Size & 2158 & $13,95 * * *$ & 2,19 & 8,96 & 19,59 & 2412 & $13,99 * * *$ & 2,13 & 8,96 & 18,65 \\
\hline Profitability & 2145 & $0,57 \% * * *$ & $1,98 \%$ & $-3,92 \%$ & $14,55 \%$ & 2244 & $0,69 \% *$ & $2,00 \%$ & $-3,85 \%$ & $13,45 \%$ \\
\hline Capitalization & 2140 & $14,30 \% * * *$ & $17,64 \%$ & $1,59 \%$ & $87,62 \%$ & 2226 & $14,51 \% * * *$ & $17,25 \%$ & $1,43 \%$ & $87,34 \%$ \\
\hline \multicolumn{11}{|c|}{ Panel F: Macroeconomic Variables } \\
\hline GDP & 2604 & $0,69 \%$ & $2,04 \%$ & $-9,13 \%$ & $8,56 \%$ & 2604 & $2,21 \% * * *$ & $1,64 \%$ & $-0,44 \%$ & $25,16 \%$ \\
\hline Saving Propensity & 2604 & $25,39 \%$ & $8,94 \%$ & $8,33 \%$ & $52,35 \%$ & 2604 & $27,10 \%$ & $9,33 \%$ & $10,27 \%$ & $57,08 \%$ \\
\hline Inflation & 2508 & $1,83 \%$ & $1,02 \%$ & $-1,31 \%$ & $4,98 \%$ & 2508 & $0,97 \%$ & $0,79 \%$ & $-1,74 \%$ & $3,72 \%$ \\
\hline
\end{tabular}

Note: LLR_GL is the ratio of loan loss reserves-to-gross loans. LLP_GL is the ratio of loan loss provision-to-gross loans. NPL ratio is the natural logarithm of the ratio between non-performing loans and total gross loans. Z-Score is the number on a logarithmic scale of standard deviations that the bank's profitability (ROA) have to fall below the average for the bank to become insolvent. Funding structure is the ratio of total bank customer deposits-to-total assets. Asset structure is the ratio bank gross loans-to-total assets. Size is the natural logarithm of bank total assets. Profitability is the return on assets, which is the yearly net income-to-total assets ratio. Capitalization is the ratio of equity-to-total assets. GDP is the growth rate of the gross domestic product. Saving propensity is the ratio domestic savings-to-GDP. Inflation is the rate of increase in prices for goods and services. T-test difference in means between Mean treatment and Mean control prior and after the European Banking Union is also reported. $* * *, * * *$ indicate statistical significance at $1 \%, 5 \%$ and $10 \%$, respectively. 
Table 3

The effect of the Banking Union on LLR_GL and LLP_GL

[3]

[3]

[4]

[5]

[6]

[7]

LLR_GL LLP_GL LLR_GL LLP_GL

LLR_GL LLP_GL LLR_GL LLP_GL

\begin{tabular}{|c|c|c|c|c|c|c|c|c|}
\hline Centralised Supervision & $\begin{array}{c}-\mathbf{0 . 0 0 9 4} * * * \\
(0.0031)\end{array}$ & $\begin{array}{c}-0.0051 * * * \\
(0.0019)\end{array}$ & $\begin{array}{c}-\mathbf{- 0 . 0 0 8 9} * * * \\
(\mathbf{0 . 0 0 3 0})\end{array}$ & $\begin{array}{c}-0.0040 * * \\
(0.0016)\end{array}$ & $\begin{array}{c}-\mathbf{- 0 . 0 0 5 7} * * \\
(0.0027)\end{array}$ & $\begin{array}{l}-\mathbf{- 0 . 0 0 2 7} * \\
(0.0015)\end{array}$ & $\begin{array}{c}-\mathbf{- 0 . 0 0 8 2} * * * \\
(0.0028)\end{array}$ & $\begin{array}{c}-0.0032 * * \\
(0.0015)\end{array}$ \\
\hline Funding Structure & & & $\begin{array}{c}0.0095 \\
(0.0082)\end{array}$ & $\begin{array}{l}-0.0056^{*} \\
(0.0029)\end{array}$ & $\begin{array}{c}0.0074 \\
(0.0084)\end{array}$ & $\begin{array}{l}-0.0037 \\
(0.0029)\end{array}$ & $\begin{array}{c}0.0074 \\
(0.0084)\end{array}$ & $\begin{array}{l}-0.0053^{*} \\
(0.0029)\end{array}$ \\
\hline Asset Structure & & & $\begin{array}{c}0.0001 \\
(0.0095)\end{array}$ & $\begin{array}{l}-0.0028 \\
(0.0028)\end{array}$ & $\begin{array}{l}-0.0015 \\
(0.0094)\end{array}$ & $\begin{array}{l}-0.0036 \\
(0.0028)\end{array}$ & $\begin{array}{l}-0.0034 \\
(0.0086)\end{array}$ & $\begin{array}{l}-0.0031 \\
(0.0028)\end{array}$ \\
\hline Size & & & $\begin{array}{l}-0.0009 \\
(0.0012)\end{array}$ & $\begin{array}{c}-0.0008 * * \\
(0.0004)\end{array}$ & $\begin{array}{l}-0.0012 \\
(0.0012)\end{array}$ & $\begin{array}{c}-0.0008 * * \\
(0.0004)\end{array}$ & $\begin{array}{l}-0.0017 \\
(0.0012)\end{array}$ & $\begin{array}{c}-0.0009 * * \\
(0.0004)\end{array}$ \\
\hline Profitability & & & $\begin{array}{c}-0.0049 * * * \\
(0.0011)\end{array}$ & $\begin{array}{c}-0.0048 * * * \\
(0.0007)\end{array}$ & $\begin{array}{c}-0.0043 * * * \\
(0.0011)\end{array}$ & $\begin{array}{c}-0.0042 * * * \\
(0.0007)\end{array}$ & $\begin{array}{c}-0.0051 * * * \\
(0.0012)\end{array}$ & $\begin{array}{c}-0.0047 * * * \\
(0.0008)\end{array}$ \\
\hline Capitalization & & & $\begin{array}{c}0.0007 * * \\
(0.0003)\end{array}$ & $\begin{array}{l}-0.0001 \\
(0.0001)\end{array}$ & $\begin{array}{c}0.0006^{* *} \\
(0.0003)\end{array}$ & $\begin{array}{l}-0.0000 \\
(0.0001)\end{array}$ & $\begin{array}{c}0.0006^{* *} \\
(0.0003)\end{array}$ & $\begin{array}{c}-0.0001 \\
(0.0001)\end{array}$ \\
\hline GDP & & & & & & & $\begin{array}{c}0.0015 * * * \\
(0.0006)\end{array}$ & $\begin{array}{c}-0.0008 * * * \\
(0.0002)\end{array}$ \\
\hline Saving Propensity & & & & & & & $\begin{array}{c}-0.0019 * * * \\
(0.0007)\end{array}$ & $\begin{array}{l}-0.0001 \\
(0.0002)\end{array}$ \\
\hline Inflation & & & & & & & $\begin{array}{c}-0.0031 * * \\
(0.0015)\end{array}$ & $\begin{array}{c}-0.0018 * * \\
(0.0008)\end{array}$ \\
\hline Observations & 3,048 & 3,331 & 2,996 & 3,277 & 2,996 & 3,277 & 2,861 & 3,146 \\
\hline R-squared & 0.267 & 0.141 & 0.359 & 0.175 & 0.342 & 0.180 & 0.364 & 0.167 \\
\hline Number of banks & 487 & 527 & 480 & 520 & 480 & 520 & 456 & 497 \\
\hline Country Fixed Effects & YES & YES & YES & YES & NO & NO & YES & YES \\
\hline Time Fixed Effects & YES & YES & YES & YES & NO & NO & YES & YES \\
\hline Country*Time Fixed Effects & NO & NO & NO & NO & YES & YES & NO & NO \\
\hline
\end{tabular}

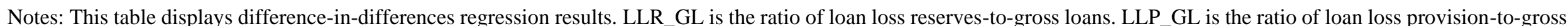

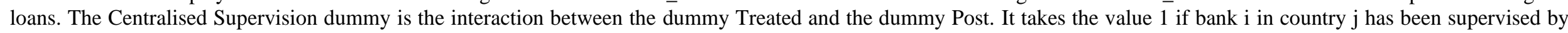

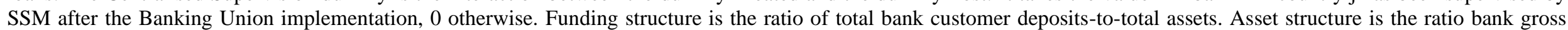
loans-to-total assets. Size is the natural logarithm of bank total assets. Profitability is the return on assets, which is the yearly net income-to-total assets ratio. Capitalization is the

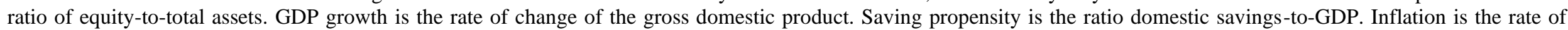

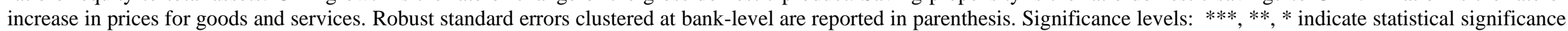
at $1 \%, 5 \%$ and $10 \%$, respectively. 
Table 4

Robustness checks

\begin{tabular}{|c|c|c|c|c|}
\hline & \multicolumn{2}{|c|}{$\begin{array}{l}\text { Panel A. Credit and Overall } \\
\text { Risk }\end{array}$} & \multicolumn{2}{|c|}{ Panel B. Fictitious Banking Union } \\
\hline & [1] & {$[2]$} & [3] & [4] \\
\hline & NPL Ratio & Z-Score & LLR_GL & LLP_GL \\
\hline Centralised Supervision & $\begin{array}{c}-\mathbf{- 0 . 3 1 1 1} * * \\
(0.1564)\end{array}$ & $\begin{array}{c}\mathbf{0 . 1 0 2 8}^{* * * *} \\
(0.0362)\end{array}$ & $\begin{array}{c}\mathbf{- 0 . 0 0 2 6} \\
(0.4602)\end{array}$ & $\begin{array}{c}\mathbf{- 0 . 0 0 0 8} \\
(0.0012)\end{array}$ \\
\hline Observations & 452 & 4,044 & 3,655 & 4,077 \\
\hline R-squared & 0.485 & 0.0874 & 0.388 & 0.162 \\
\hline Number of banks & 115 & 658 & 457 & 498 \\
\hline Country Fixed Effects & YES & YES & YES & YES \\
\hline Time Fixed Effects & YES & YES & YES & YES \\
\hline
\end{tabular}

Panel C. EU, no Germany

Panel D. EU, no France

\begin{tabular}{lcccc}
\hline & {$[1]$} & {$[2]$} & {$[3]$} & {$[4]$} \\
& LLR_GL & LLP_GL & LLR_GL & LLP_GL \\
\hline Centralised Supervision & $\mathbf{- 0 . 0 0 9 7 * * *}$ & $\mathbf{- 0 . 0 0 3 2 *}$ & $\mathbf{- 0 . 0 0 9 3 * * *}$ & $\mathbf{- 0 . 0 0 3 8 ^ { * * }}$ \\
& $(0.0031)$ & $(0.0017)$ & $(0.0032)$ & $(0.0017)$ \\
& & & & \\
Observations & 2,465 & 2,682 & 2,274 & 2,548 \\
R-squared & 0.314 & 0.146 & 0.464 & 0.188 \\
Number of banks & 384 & 416 & 363 & 403 \\
Country Fixed Effects & YES & YES & YES & YES \\
Time Fixed Effects & YES & YES & YES & YES \\
\hline
\end{tabular}

Note: Panel A displays difference-in-differences regression results of NPL ratio, which is the natural logarithm of the ratio between non-performing loans and total gross loans, and Z-Score, which is the number of standard deviations that the bank's profitability (ROA) have to fall below the average for the bank to become insolvent. Panel B displays difference-in-differences regression results of Loan Loss Reserves ratio and Loan Loss Provision ratio with "fictitious" Banking Union dummy in 2012. Panel C displays difference-indifferences regression results of Loan Loss Reserves ratio and Loan Loss Provision ratio for a sub-sample, which considers Euro-area banks except those located in Germany. Panel D displays difference-in-differences regression results of Loan Loss Reserves ratio and Loan Loss Provision ratio for a sub-sample, which considers Euro-area banks except those located in France. LLR_GL is the ratio of loan loss reserves-to-gross loans. LLP_GL is the ratio of loan loss provision-to-gross loans. The interaction dummy is the interaction between the dummy Treated and the dummy Post. It takes the value 1 if bank $i$ in country $j$ has been supervised by SSM after Banking Union implementation, 0 otherwise. Robust standard errors clustered by banks in parenthesis. Significance levels: $* * *, * * *$ indicate statistical significance at $1 \%, 5 \%$ and $10 \%$, respectively. 
Table 5

The effect of the Banking Union on non-GIPSI countries

[1]

[2]

LLR_GL

LLP_GL

\section{Centralised Supervision}

Funding Structure

Asset Structure

Size

Profitability

Capitalization

GDP

Saving Propensity

Inflation
$-0.0081 * * *$

(0.0025)

0.0006

(0.0091)

$-0.0129$

(0.0106)

$-0.0020$

(0.0014)

$-0.0054 * * *$

(0.0019)

$0.0010 * * *$

(0.0004)

$-0.0004$

(0.0010)

0.0002

(0.0005)

$-0.0007$

(0.0016)
$-0.0046^{* * *}$

(0.0023)

$-0.0013$

(0.0041)

$-0.0053$

(0.0037)

$-0.0011^{* *}$

(0.0005)

$-0.0035^{* * *}$

(0.0011)

$-0.0002$

(0.0002)

$-0.0008$

(0.0005)

$-0.0000$

(0.0002)

$-0.0022^{* *}$

(0.0010)

Observations

1,877

2,099

R-squared

0.348

0.091

Number of banks

305

337

Country Fixed Effects

YES

YES

YES

Time Fixed Effects

YES

Note: Table 5 displays difference-in-differences regression results of Loan Loss Reserves ratio and Loan Loss Provision ratio for CORE sub-sample, which considers Euro-area banks except GIPSI ones (Greece, Italy, Portugal, Spain, and Ireland). LLR_GL is the ratio of loan loss reserves-to-gross loans. LLP_GL is the ratio of loan loss provision-to-gross loans. The Centralised Supervision dummy is the interaction between the dummy Treated and the dummy Post. It takes the value 1 if bank $\mathrm{i}$ in country $\mathrm{j}$ has been supervised by SSM after Banking Union implementation, 0 otherwise. Funding structure is the ratio of total bank customer deposits-to-total assets. Asset structure is the ratio bank gross loans-to-total assets. Size is the natural logarithm of bank total assets. Profitability is the return on assets, which is the yearly net income-to-total assets ratio. Capitalization is the ratio of equity-to-total assets. GDP growth is the rate of change of the gross domestic product. Saving propensity is the ratio domestic savings-to-GDP. Inflation is the rate of increase in prices for goods and services. Robust standard errors clustered by banks in parenthesis. Significance levels: $* * *, * * *$ indicate statistical significance at $1 \%, 5 \%$ and $10 \%$, respectively. 


\section{Appendix}

\section{Table A1}

Timeline of the key steps of European Banking Union

\begin{tabular}{|c|c|c|c|}
\hline \multicolumn{3}{|c|}{ Event Data } & \multirow{2}{*}{$\begin{array}{l}\text { Description } \\
\text { De Larosière propose a report that underlines the importance of a centralized } \\
\text { system of regulation and supervision. }\end{array}$} \\
\hline 25 & February & 2009 & \\
\hline 29 & June & 2012 & $\begin{array}{l}\text { At the Euro area summit, Governments decide to assign supervisory tasks to the } \\
\text { European Central Bank (ECB) within a Single Supervisory Mechanism (SSM). }\end{array}$ \\
\hline 12 & September & 2012 & $\begin{array}{l}\text { The European Commission presents legislative proposals and formulates a road } \\
\text { map towards a banking union. }\end{array}$ \\
\hline 23 & October & 2013 & The ECB starts the comprehensive assessment. \\
\hline 3 & November & 2013 & $\begin{array}{l}\text { The SSM Regulation enters into force and states that the ECB assumes its full } \\
\text { supervisory tasks on } 4 \text { November } 2014 \text {. }\end{array}$ \\
\hline 4 & September & 2014 & The ECB publishes the list of the significant credit institution. \\
\hline 4 & November & 2014 & The SSM enters into force. \\
\hline
\end{tabular}


Table A2

Explanatory variables

\begin{tabular}{|c|c|c|c|c|}
\hline Classification & Explanatory variables & Expected signs & Data source & References \\
\hline \multicolumn{5}{|c|}{ Bank-specific variables } \\
\hline Funding Structure & $\begin{array}{l}\text { Total Customer Deposit / } \\
\text { Total Assets (\%) }\end{array}$ & $(-)$ & BankFocus & Laeven et al. (2015) \\
\hline Asset Structure & Loan / Total Assets (\%) & $(-)$ & BankFocus & Altunbas et al.(2007) \\
\hline Size & $\begin{array}{l}\text { Natural log of Total } \\
\text { Assets }\end{array}$ & $(-)$ & BankFocus & Baghat et al. (2013) \\
\hline Profitability & Return on Assets (\%) & $(-)$ & BankFocus & $\begin{array}{l}\text { Poghosyan and } \\
\text { Čihak (2011) }\end{array}$ \\
\hline Capitalization & Equity / Total Assets (\%) & $(+)$ & BankFocus & $\begin{array}{l}\text { Gambacorta and Shin } \\
(2015)\end{array}$ \\
\hline \multicolumn{5}{|c|}{ Macroeconomic variables } \\
\hline GDP & $\begin{array}{l}\text { Annual real GDP growth } \\
\text { rate }(\%)\end{array}$ & $(+/-)$ & $\begin{array}{l}\text { World } \\
\text { Bank }\end{array}$ & $\begin{array}{l}\text { Poghosyan and Čihak } \\
\text { (2011); Guidara et al. } \\
\text { (2013) }\end{array}$ \\
\hline Saving Propensity & $\begin{array}{l}\text { Gross Domestic Savings / } \\
\text { GDP }(\%)\end{array}$ & $(-)$ & $\begin{array}{l}\text { World } \\
\text { Bank }\end{array}$ & Festic et al. (2011) \\
\hline Inflation & $\begin{array}{l}\text { Annual average rate } \\
\text { change in CPI }(\%)\end{array}$ & $(-)$ & $\begin{array}{l}\text { World } \\
\text { Bank }\end{array}$ & Gerlach et al. (2005) \\
\hline
\end{tabular}

